\title{
Peran Keadilan Prosedural dan Identitas Sosial Dalam Meningkatkan Efektivitas Penerapan E-Tilang Di Jakarta (Analisis Kebijakan)
}

\section{Role of Procedural Justice and Social Identity in Improving Effectiveness of Application of E-Ticketing In Jakarta (Policy Analysis) \\ Ginanjar Maulana Faturohman \& Mirra Noor}

Universitas Indonesia

Diterima: 13 Mei 2021 Direview: 13 Mei 2021; Disetujui: 06 Agustus 2021

*Coresponding Email: mirranoor@ui.ac.id

\begin{abstract}
Abstrak
Beberapa pelangaran dilakukan oleh pengendara dapat mengakibatkan beberapa hal, yang mana hal tersebut bersifat kontra produktif. Menurut Undang-undang No 2 tahun 2009 tentang LLAJ (lalu lintas dan angkutan jalan) pasal 260 \& pasal 262 yang berwenang dalam melakukan penindakan terhadap pelanggaran lalu lintas adalah Kepolisian Negara Republik Indonesia (Polri) dan Penyidik Pegawai Negeri Sipil. Penelitian ini bertujuan untuk mengkaji secara khusus mengwnai praktik penelitian pada penerapan sistem e-Tilang di PMJ secara ilmiah untuk mencari peraturan sistem yang dilakukan oleh para pelaku kebijakan pada implementasi kebijakan dan argumen ataupun opini yang berkembang pada masyarakat yang berdampak pada kebijakan sistem e-Tilang. Pada penelitian ini menggunakan metode analisis kebijakan. Analisis kebijakan ialah suatu penelitian sosial yang menyusun penerapannya secara sistematis. Ada dua kebijakan pada penerapan e-Tilang, yaitu edukasi dan kebijakan. Pada edukasi terdapat 3 kriteria, yaitu: Meningkatkan kualitas aparat kepolisian, membentuk citra aparat kepolisian, dan mengedukasi masyarakat untuk menanamkan identitas yang baik dan taat pada hukum. Adapun kebijakan yaitu suatu aturan dan hukuman dari petugas kepolisian untuk para pungli atau pelanggar lainnya.
\end{abstract}

Kata Kunci: Lalu Lintas; Polda Metro Jaya; Undang-undang.

Abstract

Some of the violations committed by the driver can lead to several things, which it is counter productive. According to Law No. 2 of 2009 on LLAJ (traffic and road transport) of Article 260 and Article 262 are authorized to take action against violations of traffic is the Indonesian National Police (Polri) and the Civil Servant Investigators. This study aims to assess specifically mengwnai research practice in the application of e-Ticketing system in PMJ scientifically to seek regulatory system is performed by the actors in the implementation of policies and policy arguments or opinions that develop in people who have an impact on the policy of the e-Ticketing. In this study using the method of policy analysis. Policy analysis is a social study which arranges its application in a systematic manner. There are two policies on the implementation of eTicketing, namely education and policy. In education there are three criteria, namely: Improving the quality of police officers, forming the image of the police, and educate the public, to inculcate a good identity and obey the law. As for policy namely a rule and punishment from police officers for extortionists or other offenders.

Keywords: traffic; Polda Metro Jaya; Law

How to Cite: Faturohman, G.M. \& Noor, M. (2021). Peran Keadilan Prosedural dan Identitas Sosial Dalam Meningkatkan Efektivitas Penerapan E-Tilang Di Jakarta(Analisis Kebijakan),Journal of Education, Humaniora and Social Sciences (JEHSS). 4(2): 677-685. 


\section{PENDAHULUAN}

Fantastisnya jumlah pelanggaran di kota besar menjadi perhatian untuk dilakukan penelitian. Seperti yang disampaikan (Pambagio, 2016) ia menyatakan bahwa wilayah Jakarta salah satu lalu lintas yang paling padat merayap serta tindakan pungli oleh aparat yang tinggi yang muncul akibat penerapan tilang yang tidak tepat. Kepolisian Republik Indonesia mengeluarkan sistem e-Tilang sebagai suatu kebijakan dalam penilangan pada pelanggar lalu lintas yang berjalan efisien dan transparan guna untuk memudahkan warga dalam mengurus proses penilangan. Beberapa proses tilang dipangkas dengan prosedur tilang sebelumnya, pelanggar dapat membawa barang bukti yang telah disita polisi setelah membayar dan menunjukkan bukti pembayaran, dan pelanggar tidak harus menunggu keputusan sidang dan tidak perlu khawatir terhadap kecurangan dari pihak kepolisian. Oknum polisi lalu lintas melakukan sistem e-Tilang guna untuk mencegah pungutan liar. Undang-undang Nomor 22 Tahun 2009 tentang Lalu Lintas dan Angkutan Jalan, dan Perma Nomor 12 Tahun 2016 melandaskan tentang Tata Cara Penyelesaian Perkara Pelanggaran Lalu Lintas.

Dinyatakan sukses saat terjadi pro kontra pada proses penilangan ini dikarenakan adanya pembaruan sistem yang mengakibatan turunnya jumlah pelanggaran. Adanya pembaruan sistem yang mengakibatkan pro kontra pada tilang-menilang ini dinyatakan berhasil karena dapat menurunkan jumlah pelanggaran. Direktorat Lalu Lintas Kepolisian Daerah Metro Jaya dalam https://antarnews.com/berita/936670/awas-tilang-elektronik-di-jakarta menyampaikan hasil evaluasi system tilang elektronik ini bahwa pelanggaran lalu lintas di wilayah simpang Sarinah dan simpang Patung Kuda Arjuna Wiwaha dapat diturunkan menjadi 44 persen. Sementara terkait dampak etilang untuk meniadakan pungli oleh aparat menurut (Chusminah dkk, 2018) dalam penelitiannya, penindakan terhadap pungli dan calo cukup efektif dan terlibat pada implementasi sistem e-Tilang, baik internal polri ataupun stakeholder/ actor (kejaksaan dan pengadilan).

Meskipun demikian, praktik pada penerapan e-Tilang ini masih belum sepenuhnya maksimal. Menurut data dalam penggarapan terkait tilang dari Kejaksaan Agung pada bulan Januari 2017 - September 2017 (Surat Jaksa Agung RI No: B-019/A/ Ejp/01/2018 tanggal 24 Januari 2018 perihal Penyelesaian perkara pelanggaran lalu lintas/tilang) sekitar 17\% penindakan dalam penggunaan aplikasi e-Tilang yang baru terlaksana dari semua persoalan tilang dari pengadilan. Sebanyak 2.965 .073 perkara rincian data perkara yang diputuskan oleh pengadilan, adapun perkara yang ditindak dengan menggunakan aplikasi e-Tilang yaitu sebanyak 500.575 perkara (17\%). Dapat dikatakan bahwa sekitar 2.464 .498 perkara (83\%) pengelolaan masih melakukan dengan cara manual. Mengacu pada data di atas penindakan pelanggaran lalu lintas yang dilakukan secara manual masih tinggi, hal tersebut mengindikasikan bahwa masih terbuka kemungkinan untuk dilaksanakannya pungli dengan beberapa oknum dari anggota pelaku kebijakan. Dengan tujuan untuk meminimalisir perilaku koruptif belum sepenuhnya tercapai. Dijelaskan oleh Mahmudi bahwa sistem e-Tilang belum sepenuhnya otomatis masih ada peran polisi diawal memasukkan data e-Tilang yang memungkinkah terjadi "tawar menawar" untuk menentukan apakah akan diproses melalui tilang elektronik atau manual. Sehinngga dalam hal ini, penulis berasumsi bahwa dalam menjelaskan masih rendahnya angka penggunaan e-Tilang karena keputusan untuk penerapan e-Tilang masih berdasarkan keputusan aparat, yang menentukan penerapan e-Tilang, sehingga masih memberi peluang terjadinya pungli.

Selain itu sosialisasi yang belum merata pada masyarakat membuat pelanggaran masih banyak terjadi dan masyarakat merasa tidak tahu dengan adanya kebijakan e-Tilang ini (Setiyanto \& Wahyuningsih, 2017). Apriliana (2019) menambahkan bahwa kurangnya sosialisasi dari penerapan aplikasi e-Tilang dalam penindakan pelanggaran lalu lintas serta pembayaran denda pelanggaran lalu lintas membuat penggunaan e-Tilang masih minim di bandingkan tilang konvensional. Penulis berargumen bahwa kebijakan penetapan kebijakan e-Tilang yang bertujuan dalam melakukan pengurangan terhadap penindakan korupsi dengan aparat penegak hukum kepada para pelanggar yang lepas tanggung jawab dan untuk meningkatkan disiplin berlalu lintas, keselamatan dan ketertiban pada masyarakat ketika sedang mengendarai kendaraan di jalan ini sudah tepat, namun dalam penerapannya masih belum optimal (Apriliana, 2019). Menarik untuk 
diketahui lebih jauh mengapa kebijakan e-Tilang ini dalam implementasinya masih terdapat hambatan, dalam hal ini tinjauan psikologis untuk menjelaskan perubahan perilaku pengendara maupun aparat penegak hukum itu sendiri dalam menjalankan kebijakan tersebut penting untuk dikaji. Dalam hal ini penulis menawarkan konsep keadilan prosedural dalam penegakkan hukum yang tepat dan bermartabat bagi para aparat diasumsikan akan berdampak positif pada penilaian masyarakat serta mampu menumbuhkan rasa patuh di kalangan masyarakat dan aparat itu sendiri.

Selain itu penulis juga memandang penting proses edukasi dan sosialiasi terkait kebijakan tersebut melalui pembentukan norma berdasarkan identitas dengan menggunakan perspektif teori identitas sosial. Edukasi dan sosialisasi dapat ditanamkan dengan pembentukan jati diri masyarakat melalui kepatuhan berdasarkan identitas sosial, sehingga dapat diharapkan peningkatan kesadaran diri pada masyarakat sebagai warga yang patuh mampu meningkatkan kepatuhan pengendara lalu lintas dalam ketertiban berkendara secara sukarela.

Penelitian tentang penerapan sistem e-Tilang sudah banyak diteliti oleh para peneliti, namun sejauh ini belum ada yang meneliti tentang "Peran Keadilan Prosedural dan Identitas Sosial Dalam Meningkatkan Efektivitas Penerapan E-Tilang Di Jakarta". Adapun penelitian-penelitian sebelumnya yang berkaitan dengan sistem e-Tilang adala:

Pertama, penelitian yang dilakukan oleh Ambar Suci Wulandari (2020) yang berjudul "Inovasi Penerapan Sistem E-Tilang Di Indonesia". Penelitian ini bertujuan untuk melayani publik yang diberikan dapat lebih transparan, akuntabel, efektif dan efisien untuk mewujudkan pemerintahan yang baik. Isu penting dalam hal ini berkaitan dengan inovasi penerapan sistem etilang serta urgensi e-tilang yang ada saat ini dilihat dari manfaatnya (Ambar, 2020).

Kedua, peneltian yang dilakukan oleh Agung Asmara, A Wahyurudhanto, dan Sutrisno yang berjudul "Penegakan Hukum Lalu Lintas Melalui Sistem e-Tilang". Penelitian ini bertujuan Penelitian ini bertujuan untuk mengungkap masalah berkaitan dengan penegakan hukum melalui implementasi kebijakan sistem e-Tilang, kendala yang dihadapi dan pandangan masyarakat terkait penegakkan hukum e-Tilang di wilayah hukum PMJ(Agung dkk, 2019).

Ketiga, penelitian yang dilakukan oleh Rakhmi Khalida dan Siti Setiawati yang berjudul "Analisis Sentimen Sistem E-Tilang Menggunakan Algoritma Naive Bayes Dengan Optimalisasi Information Gain". Penelitian ini bertujuan untuk memperbaiki sistem pelayanan publik dalam pelanggaran berlalu-lintas yaitu dengan menerapkan sistem e-Tilang. Sistem ini menjadi solusi mendisiplinkan para pengendara kendaraan bermotor dari banyaknya melakukan pelanggaran berlalu-lintas (Rakhmi \& Setiawati, 2020).

Penelitian ini bertujuan untuk mengkaji secara khusus mengwnai praktik penelitian pada penerapan sistem e-Tilang di PMJ secara ilmiah untuk mencari peraturan sistem yang dilakukan oleh para pelaku kebijakan pada implementasi kebijakan dan argumen ataupun opini yang berkembang pada masyarakat yang berdampak pada kebijakan sistem e-Tilang.

\section{METODE PENELITIAN}

Metode yang digunakan penulis ialah metode analisis kebijakan, guna untuk menganalisis efektivitas kebijakan e-Tilang di wilayah DKI Jakarta. Metode ini merupakan penyusunan penerapan pada penelitian sosial yang sistematis ini dapat dilihat dari suatu kebijakan nilai substansi, supaya informasi yang berkaitan dengan masalah-masalah dapat dijawab oleh kebijakan secara jelas dan timbul masalah-masalah dari penerapan kebijakan (Dunn, 2011). Umumnya, metode dan ruang lingkup pada metode ini dapat disebut dengan deskriptif dan faktual. Informasi yang berhubungan dengan masalah kebijakan, aksi kebijakan, masa depan kebijakan, kinerja kebijakan, dan hasil kebijakan.

Analisis kebijakan merupakan analisis yang menerapkan berbagai metode penelitian yang tujuannya mencari data yang signifikan pada suatu kebijakan dan mampu menyimpulkan masalah-masalah publik yang terbilang rumit hingga menjadi lebih tersusun, yang membuat penulis menjadi lebih mudah dalam menyimpulkan suatu pemasalahan dalam kebijakan kepada pembuat kebijakan (Kustriani, 2015). 
Terdapat 5 analisis kebijakan yang sering digunakan dalam penyelesaian masalah manusia, diantaranya; definisi, prediksi, preskripsi, deskripsi serta evaluasi. Lebih jelasnya lagi yang dijelaskan oleh Dunn, yang menunjukkan bahwa orientasi pada analisis kebijakan ini dapat dihubungkan antar lima informasi kebijakan dan prosedur kebijakan, seperti yang terlihat pada gambar 1.

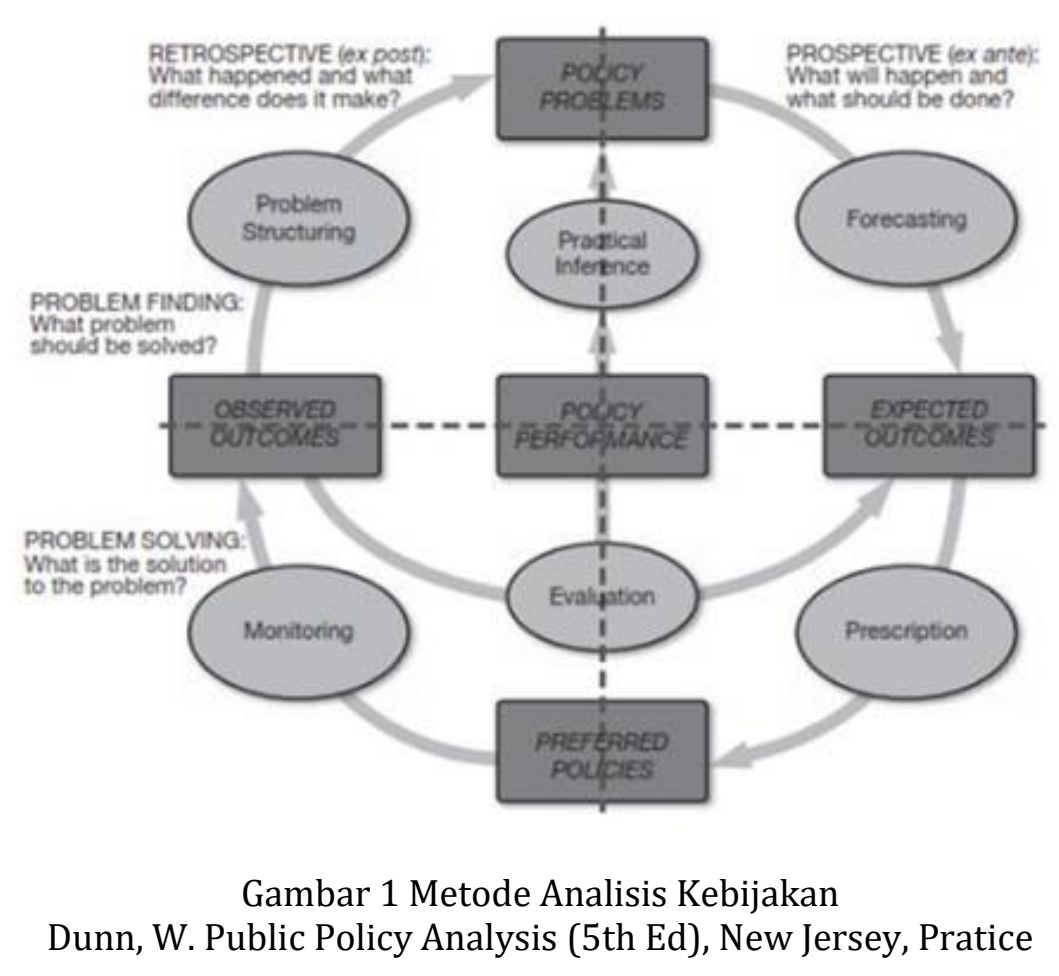

Berdasarkan kerangka metode analisis kebijakan dari Dunn, dalam paper ini, penulis akan berfokus pada bagian Pemantauan (Monitoring) dan Evaluasi (Problem Structuring) dari kebijakan E-tilang di DKI Jakarta. Dimana Penulis ingin mengetahui sejauh mana efektifitas penerapan kebijakan tersebut.

\section{HASIL DAN PEMBAHASAN}

\section{Permasalahan Pelanggaran Lalu Lintas}

Tertib, lancar dan selamat di lingkungan lalu lintas merupakan lalu lintas yang teladan. Masyarakat yang memproduktifkan hidupnya, dengan kata lain lalu lintas seperti urat nadi kehidupan (Chrisnanda, 2017). Beberapa pelangaran dilakukan oleh pengendara dapat mengakibatkan beberapa hal, yang mana hal tersebut bersifat kontra produktif. Seperti; pelanggaran yang mengakibatkan terjadinya pelanggaran atau kecelakaan lainnya yang mengakibatkan masalah pada lalu lintas. Kemudian pelanggaran tersebut dapat dilakikan dengan penindakan pada pelanggaran lalu lintas. Menurut Undang-undang No 2 tahun 2009 tentang LLAJ (lalu lintas dan angkutan jalan) pasal 260 \& pasal 262 yang berwenang dalam melakukan penindakan terhadap pelanggaran lalu lintas adalah Kepolisian Negara Republik Indonesia (Polri) dan Penyidik Pegawai Negeri Sipil. Perbuatan tilang merupakan bukti salah satu pelanggaran yang berupakan denda kepada pelanggar lalu lintas.

\footnotetext{
680 http://mahesainstitute.web.id/ojs2/index.php/jehss mahesainstitut@gmail.com

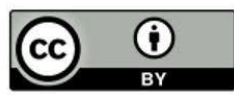


Tabel 1.1

Data Penindakan Pelanggaran dan Laka Lantas Selama Tahun 2015-2018 PMJ

\begin{tabular}{|c|c|c|c|c|c|c|c|c|}
\hline No & Uraian & & & Tahun & & & Trend & \\
\hline & & 2015 & 2016 & 2017 & 2018 & $\begin{array}{c}2015- \\
2016\end{array}$ & $\begin{array}{l}2016- \\
2017\end{array}$ & $\begin{array}{l}2017- \\
2018\end{array}$ \\
\hline 1 & $\begin{array}{c}\text { Penindakan } \\
\text { Gar } \\
\text { (Tilang) }\end{array}$ & 1.037 .828 & 1.306 .060 & 1.062 .900 & 1.144 .752 & $20,5 \%$ & $-22,9 \%$ & $7,2 \%$ \\
\hline 2 & $\begin{array}{c}\text { Jumlah } \\
\text { Kecelakaan } \\
\text { Lalu Lintas }\end{array}$ & 6.43 & 6.180 & 5.642 & 5.903 & $-4,1 \%$ & $-9,5 \%$ & $4,4 \%$ \\
\hline 3 & $\begin{array}{l}\text { Korban MD } \\
\text { (Meninggal } \\
\text { Dunia) }\end{array}$ & 591 & 678 & 571 & 567 & $12,8 \%$ & $-18,7 \%$ & $-0,7 \%$ \\
\hline 4 & $\begin{array}{c}\text { Korban LB } \\
\text { (Luka } \\
\text { Berat) }\end{array}$ & 2.688 & 2.250 & 1.098 & 867 & $-19,5 \%$ & $105 \%$ & $-27 \%$ \\
\hline 5 & $\begin{array}{l}\text { Korban LR } \\
\text { (Luka } \\
\text { Ringan) }\end{array}$ & 4.290 & 4.487 & 4.964 & 5.724 & $4,4 \%$ & $9,6 \%$ & $13,3 \%$ \\
\hline 6 & $\begin{array}{l}\text { Jumlah } \\
\text { Korban } \\
(3+4+5)\end{array}$ & 7.569 & 7.415 & 6.633 & 7.158 & $-2,1 \%$ & $-11,8 \%$ & $7,3 \%$ \\
\hline 7 & $\begin{array}{l}\text { Kerugian } \\
\text { Materil }\end{array}$ & 9.535 & 8.985 & 8.090 & 8.378 & $-6,1 \%$ & $-11,1 \%$ & $3,5 \%$ \\
\hline 8 & $\begin{array}{l}\text { Rupiah } \\
\text { Miliar }\end{array}$ & 18,5 & 21,9 & 16,7 & 14,2 & $15,5 \%$ & $-31,1 \%$ & $-18 \%$ \\
\hline
\end{tabular}

Dari Tabel 1. tentang Data Penindakan Pelangaran dan Kecelakaan Lalu Lintas sepanjang periode 2015 sampai dengan 2018 milik Polda Metro Jaya (PMJ) di atas dapat digambarkan yakni kota besar memiliki beberapa jumlah pelanggaran yang hebat, sehingga peneliti tertarik untuk melakukan penelitian ini. Sama seperrti yang dikatakan oleh (Pambagio, 2016) bahwa yang dapat dijadikan contoh lalu lintas yang padat merayap di negeri ini adalah Jakarta, karena angka pelanggarannya bisa dikatakan menarik untuk peneliti kaji. Sementara Polda Metro Jaya melaksanakan penindakan terhadap pelanggar lalu lintas pada tahun 2016 penurunan angka laka lantas tidak berbanding lurus, oleh karena itu penurunan jumlah angka akibat kecelakaan lalu lintas belum memperlihatkan pengaruh yang signifikan pada penindakan suatu pelanggaran. Dibandingkan dengan tahun lalu, pada tahun 2017 penurunan pada penindakan pelanggaran turun hingga $22,9 \%$ hingga mengalami penurunan pada kecelakaan yang dialami sebesar 9,5\%. Dengan demikian, peningkatan pada penegakkan pelanggaran belum menunjukkan dampak turunnya angka pada kecelakaan lalu lintas. Hal tersebut bisa disebabkan oleh pengaruh lainnya,

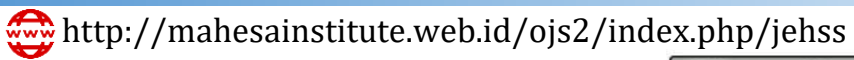


hal ini bisa disebabkan juga karena terjadinya pelanggaran lalu lintas sebelum terjadinya kecelakaan (Wayne, 2020).

Seperti yang telah dipaparkan pada latar belakang, peneliti memiliki pandangan terkait penerapan dari PMJ yang belum terlaksana secara optimal dalam praktik penerapan sistem eTilang. Hal tersebut dikarenakan pada praktik penelitian ini perlu mengadakan riset pada penerapan sistem e-Tilang dalam mencari peraturan sistem di PMJ yang dilaksanakan oleh pelaku kebijakan serta memberi argumen dan opini untuk masyarakat yang berkembang dan memberi dampak pada sistem e-Tilang, agar penerapan tersebut bisa dioptimalkan dalam mencegah penyimpangan terhadap peradaban dan pelanggaran tata tertib lalu lintas.

\section{Perumusan Kebijakan Sistem e-Tilang di DKI Jakarta}

Terdapat 3 pertimbangan yang dimiliki oleh sistem e-Tilang, diantaranya: 1) peradilan yang diselenggarakan dapat dilakukan dengan mudah, gesit, dan ringan biaya agar dapat meluaskan akses bagi masyarakat dalam mendapatkan keadilan. 2) lembaga yang mendapatkan amanat untuk menyelenggarakan dalam mengelola perkara pelanggaran lalu lintas berdasarkan Undangundang Nomor 8 Tahun 1981 tentang KUHAP dan UU No. 2 tahun 2009 tentang LLAJ dan aturan undang-undang yang berkaitan dengan lainnya yaitu Pengadilan beserta Kepolisian dan Kejaksaan. Ketiga, bahwa menyelesaikan dan mengelola perkara terkait pelanggaran lalu lintas tidak terlalu optimal, sehingga perlu melakukan pengaturan supaya pelayanan publik dan keadilan bisa dirasakan oleh para masyarakat dan yang mencari keadilan.

\section{Sosialisasi dan Komunikasi Kebijakan Sistem e-Tilang di DKI Jakarta}

Dalam menyampaikan informasi tentang kebijakan yang dibuat dengan melakukan komunikasi dan sosialisasi yang dikeluarkan oleh instansi kepolisian, seperti petunjuk, arahan dan perintah dari Korlantas Polri ataupun dari Direktorat Lalu Lintas PMJ dan adanya kekurangpahaman pada internal ataupun eksternal organisasi oleh lembaga yang belum tersosialisasikan baik itu kebijakan yang dibuat ataupun yang disepakati. Dalam melakukan sosialisasi, petugas hanya melakukan satu kali dengan melalui pelatihan yang dilaksanakan bersama Bank BRI di BRI Coorporate University secara internal. Dalam penyelenggaraan pelatihan tersebut menghadirkan perwakilan dari tiap polres untuk melanjutkan informasi yang diterima oleh petugas yang belum mengikuti. Adanya perbedaan yang ditemukan dengan pelaksanaan di lapangan dalam pesepsi konsep praktik pada penerapan sistem e-Tilang menurut per-MA dan SOP. Adapun yang dilakukan secara eksternal yang disimpulkan oleh PMJ terkait proses sosialisasi praktik penerapan sistem e-Tilang bahwa pelaksanaan sosialissasi kebijakan sistem e-Tilang dari petugas polisi lapangan kepada masyarakat secara langsung belum memiliki dampak yang signifikan, hanya sekitar $22 \%$ pengemudi yang mengetahui informasi langsung dari petugas informasi. Ini disebabkan adanya kebijakan keselamatan lalu lintas yang disosialisasikan beberapa saat sebelum dan sesudahnya kebijakan tersebut diumumkan. Sehingga sosialisasi yang dilakukan oleh petugas belum ada yang tersentuh dari anggota masyarakat (Sutrisno, 2019).

Menurut penelitian Sutrisno, (2019) beberapa masalah dalam penerapan kebijakan Etilang adalah diantaranya sebagai berikut: Pertama, kurangnya sumber daya manusia yang dimiliki para petugas saat melaksanakan praktik penerapan sistem e-Tilang di PMJ dikarenakan belum melaksanakan pendidikan dan pelatihan tentang penegakkan hukum e-Tilang dari sebagian besar petugas penindak lapangan. Petugas yang mengikuti pelatihan diharuskan untuk melaksanakan snow ball (pembagian materi saat sosialisasi kepada rekan petugas lainnya) namun ada beberapa hal yang belum tersampaikan karena tuntutan dari sosialisasi kepada rekannya. Dengan standar spesifikasi tertentu, personil yang mengimplementasikan e-Tilang dengan smartphone tidak bisa mendapatkan sumber daya materi di lapangan. Pada praktik penerapan sistem e-Tilang, Sumber Daya Anggaran tidak didukung dalam DIPA, yang didukung hanyalah dana insentif dari PNBP, senilai Rp 10.000,00 yang harus dibagikan kepada rekan-rekan untuk keperluan porasional barang bukti yang belum teralokasikan untuk insentif. Kedua, adanya inkonsistensi pada penerapan sistem e-Tilang pada disposisi praktik penerapan saat melaksanakan penindakan di lapangan. Hal ini terbukti oleh data yang diperoleh belum optimal dari hasil crosstab. Meski 63्w http://mahesainstitute.web.id/ojs2/index.php/jehss

(v) mahesainstitut@gmail.com

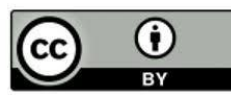


demikian, masih ada beberapa petugas yang sesuai dengan prosedur walaupun tidak melaksanakan praktik penerapan e-Tilang.

Beberapa penyebab dari belum optimalnya penerapan e-Tilang juga dijelaskan oleh (Mahmudi, 2005) yang menjelaskan adanya kelemahan pada kebijakan e-Tilang seperti misalnya, ada pengendara yang ketahuan melanggar dan petugas lalu lintas merupakan polisi yang memiliki otoritas memberikan tilang. Apabila petugas ini ingin berbuat curang, pasti dia memutuskan untuk tidak mencataa sebagai pelanggar di aplikasi tersebut. Apalagi jika adanya tawar-menawar dengan pengendara. Bisa jadi ini sebagai pengingat besarnya denda yang semestinya dibayar. Selain itu Wayne (2020) menjelaskan proses e-Tilang yang tidak efisien yaitu adanya proses pengisian identitas yang harus dilaksanakan dua kali karena perlu di salin ke Blangko Biru sebelum pelanggar teregistrasi dengan e-Tilang, hal ini mendorong penggunaan manual tilang dan peluang untuk terjadiya praktek suap masih ada. Dijelaskan pulan bahwa adanya masyarakat yang tidak mentaati prosedur pada sistem e-Tilang ini, dikarenakan masih banyaknya dari mereka yang belum mengetahui sistem tersebut, juga menjadi kesulitan dalam melakukan proses pembayaran denda maupun pengembalian kendaraan yang disita kepolisian (Wayne, 2020).

\section{Pendekatan Keadilan Prosedural dan Identitas Sosial untuk Meningkatkan Kepatuhan}

Penelitian yang dilakukan terkait keadilan procedural secara konsisten menunjukkan bahwa ketika petugas polisi memperlakukan orang dengan adil, bermartabat, dan hormat, orang-orang ini lebih cenderung memandang polisi sebagai penegak hukum yang sah, lebih cenderung mengatakan mereka akan manut dan membantu petugas di kemudian hari, dan cenderung tidak melaporkan keburukan petugas. Orang yang percaya bahwa lembaga peradilan adalah pemegang kekuasaan yang sah lebih cenderung taat hukum karena mereka menginternalisasi nilai moral untuk mematuhi hukum (Jackson, 2013)

Thibaut mengatakan bahwa adanya pengaruh besar pada proses pengambilan keputusan terhadap penerimaan terkait hasil dari suatu keputusan. Hal yang wajar jika ada yang tidak setuju dengan keputusan tersebut, namun keputusan tersebut diterima karena sudah diberlakukan dengan adil. Menurut Kozlowski (2012) keadilan procedural adalah suatu proses untuk ikut serta pada pencapaian dari hasil kriteria-kriteria agar terpenuhi prosedur yang adil seperti, konsisten, akurat, bebas bias, dan etis (Kozlowski \& Bell, 2012).

Keadilan procedural dapat mendorong kepatuhan pada warga dan masyarakat. Kepatuhan lebih didasari oleh pengalaman mendapatkan penegakkan hukum yang baik, adil, dan sah secara procedural. Sementara penerapan Sanksi atau denda berkorelasi lemah terhadap kepatuhan (Jackson, 2014). Keadilan procedural mendorong tumbuhnya kepatuhan masayarakat yang tumbuh karena didasari kepercayaan masyarakat terhadap aparat yang jujur dan menegakkan hukum dengan baik dan benar. Stakeholder yang baik dan adil membuat masyarakat "Terpuaskan", sehinga muncul timbal balik rasa PERCAYA, dan tumbuh perasaan Wajib untuk mematuhi aturan (Hough dkk, 2013). Keadilan procedural dapat memperkuat identifikasi dengan kelompok yang diwakili oleh polisi, lalu dapat memotivasi legitimasi otoritas kelompok (yaitu, polisi). Ketika orang mengidentifikasi lebih kuat dengan sebuah kelompok, dalam hal ini kesatuan polisi, maka masyarakat akan termotivasi untuk mendukung dan melegitimasi otoritasnya, dan muncul keinginan untuk menjadi bagian serta bekerja sama di dalamnya dan atas Namanya (Bradford dkk, 2015).

Sementara itu, untuk meningkatkan kepatuhan selain melalui prosedur yang dipersepsi adil oleh berbagai pihak yang terlibat, kepatuhan juga dapat dibentuk melalui norma kelompok berdasarkan identitas. Dalam hal ini teori identitas sosial dapat digunakan untuk menjelaskan hal tersebut. Dijelaskan oleh teori identitas sosial, bahwa identitas diri terkait erat dengan peran, dimana mengidentifikasi diri sebagai anggota kelompok tertentu juga menerima serangkaian peran tertentu yang mendefinisikan identitas ini. Polisi yang adil akan memperkuat hubungan dengan komunitas, sehingga menciptakan identitas sosial pada masyarakat bahwa " kami adalah warga yang taat hukum" (Bradford dkk, 2015). Argumen yang diajukan oleh penulis dalam hal ini adalah intervensi melalui penguatan identitas sosial pada masyarakat Jakarta khsususnya yang taat hukum dapat menguatkan terbentuknya norma kepatuhan bagi warga masyarakat. 
Ginanjar Maulana Faturohman \& Mirra Noor Milla, Peran Keadilan Prosedural dan Identitas Sosial Dalam Meningkatkan Efektivitas Penerapan E-Tilang Di Jakarta (Analisis Kebijakan)

\section{Rekomendasi Kebijakan}

Berdasarkan konsep keadilan procedural dan teori identitas sosial, penulis merekomendasikan beberapa hal di bawah ini untuk meningkatkan efisiensi penerapan kebijakan e-Tilang :

Edukasi. Meningkatkan kualitas aparat kepolisian yang bertugas sehingga memiliki integritas tinggi dalam berperilaku adil, bermartabat, dan hormat sehingga dapat menjalankan visinya dengan melaksanakan suatu pembinaan perbaikan kualitas terhadap petugas lalu lintas, sebagaimana aparat yang Profesional, Modern, dan Transparan. Serta menanamkan keyakinan bahwa bila aparat berperilaku adil yaitu konsisten, akurat, bebas bias, dan etis maka masyarakat akan menjadi patuh dengan sendirinya.

Membentuk Citra Aparat kepolisian menjadi penegak hukum agar dapat menegakkan hukum secara professional, modern, dan terpercaya. Edukasi untuk masyarakat dengan cara menanamkan identitas masyarakat yang baik dan Masyarakat taat hukum bisa melalui penyuluhan kesadaran nilai nilai bangsa dan warga negara yang baik dan taat hukum

Kebijakan. Adanya Aturan dan hukuman yang jelas terhadap polisi atau petugas yang melakukan pungli, atau petugas yang memperlakukan pelanggar dengan tidak jujur dan tidak baik, pelaksanaan hukuman untuk petugas /aparat ini pun dilakukan secara transparan sehingga secara tidak langsung melegitimasi dan memperkuat integritras Lembaga atau instansi tempat petugas tersebut bernaung sebagai lembaga yang adil dan terpercaya serta mampu menimbulkan dampak positif dengan mendorong tumbuhnya kepatuhan masayarakat yang tumbuh karena didasari kepercayaan masyarakat terhadap aparat yang jujur dan menegakkan hukum dengan baik dan benar. Stakeholder yang baik dan adil membuat masyarakat "Terpuaskan", sehingga muncul timbal balik rasa PERCAYA, dan tumbuh perasaan wajib untuk mematuhi aturan (Hough dkk, 2013).

\section{SIMPULAN}

Dari Tabel tentang Data Penindakan Pelangaran dan Kecelakaan Lalu Lintas sepanjang periode 2015 sampai dengan 2018 milik Polda Metro Jaya (PMJ) di atas dapat digambarkan yakni kota besar memiliki beberapa jumlah pelanggaran yang hebat, sehingga peneliti tertarik untuk melakukan penelitian ini. Pada sistem e-Tilang ini memiliki 3 pertimbangan. Yaitu; pertama, menyelenggarakan peradilan. Kedua, lembaga yang mendapatkan amanat untuk menyelenggarakan perkara pelanggaran lalu lintas. Ketiga, dalam penyelesaian dan pengelola terhadap pelanggaran lalu lintas yang belum optimal. Terdapat dua kebijakan pada penerapan eTilang, yaitu edukasi dan kebijakan. Pada edukasi terdapat 3 kriteria, yaitu: Meningkatkan kualitas aparat kepolisian, membentuk citra aparat kepolisian, dan mengedukasi masyarakat untuk menanamkan identitas yang baik dan taat pada hukum. Adapun kebijakan yaitu suatu aturan dan hukuman dari petugas kepolisian untuk para pungli atau pelanggar lainnya.

\section{DAFTAR PUSTAKA}

Agung dkk, A. W. dan S. (2019). Penegakan Hukum Lalu Lintas Melalui Sistem e-Tilang. Jurnal Ilmu Kepolisian, 13(3), 187-202.

Ambar, S. W. (2020). INOVASI PENERAPAN SISTEM E-TILANG DI INDONESIA. Jurnal Studi Islam Dan Sosial, 14(1), 1-10.

Apriliana, L. Z. (2019). EFEKTIVITAS PENGGUNAAN E-TILANG TERHADAP PELANGGARAN LALU LINTAS DI POLRES MAGELANG. Jurnal Komunikasi Hukum, 5(2), 1-11.

Bradford dkk, J. \& M. (2015). Obeying the rules of the road: Keadilan procedural, social identity, and normative compliance. Journal of Contemporary Criminal Justice, 31(2), 171-191.

Chrisnanda, D. (2017). Pengaruh motivasi kerja terhadap kinerja karyawan di PT Mas Sumbiri. Sanata Dharma.

Chusminah dkk, A. H. dan D. K. (2018). Efektifitas Implementasi E-Tilang Kendaraan Bermotor Dalam Rangka Tertib Berlalu Lintas Pada Korps Lalu Lintas Polri. Jurnal Sekretariat Dan Manajemen, 2(2), 217-224.

Dunn, W. N. (2011). Public Policy Analysis. Prentice-Hall.

684 http://mahesainstitute.web.id/ojs2/index.php/jehss mahesainstitut@gmail.com


Hough dkk, M. J. \& B. (2013). Legitimacy, trust and compliance: An empirical test of procedural justice theory using the European Social Survey. Legitimacy and Criminal Justice: An International Exploration, 326352.

Jackson, T. \&. (2013). Future challenges in the study of legitimacy and criminal jus- tice. In J. Tankebe \& A. Liebling (Eds.), Legitimacy and criminal justice: An international exploration. Oxford University Press.

Jackson, T. \&. (2014). Popular legitimacy and the exercise of legal authority: Motivating compliance, cooperation and engagement. Psychology, Public Policy and Law, 78-95.

Kozlowski \& Bell. (2012). Work groups and teams in organizations Handbook of Psychology. 12.

Kustriani, S. H. W. (2015). Modul Pelatihan Analisis Kebijakan. Lembaga Administrasi Negara Republik Indonesia.

Pambagio, A. (2016). e-Tilang Versus Pungli di Jalan Raya. DetikNews. https://news.detik.com/kolom/d3380714/e-tilang-versus-pungli-di-jalan-raya

Rakhmi \& Setiawati, K. dan S. (2020). Analisis Sentimen Sistem E-Tilang Menggunakan Algoritma Naive Bayes Dengan Optimalisasi Information Gain. Journal of Information and Information Security, 1(1), 19-26.

Setiyanto \& Wahyuningsih. (2017). Efektivitas Penerapan Sanksi Denda E-Tilang Bagi Pelanggar Lalu Lintas Berdasarkan Undang-Undang Nomor 22 Tahun 2009 Tentang Lalu Lintas Dan Angkutan Jalan (Studi Di Polres Rembang). Jurnal Hukum Khaira Ummah, 12, 742-766.

Sutrisno. (2019). Penegakan Hukum Lalu Lintas Melalui Sistem e-Tilang. Jurnal Ilmu Kepolisian, $13(3), 16$.

Wayne, A. M. (2020). Efektivitas Penerapan E-Tilang dalam Penindakan Pelanggaran Lalu Lintas di Wilayah Hukum Polres Banyumas. Police Studies Review, 4(1), 57-120. 